\title{
Seasonal variations of biogeochemical processes affecting Greek rivers composition
}

\author{
NiKos TH. SKOULIKIDIS and JoSEPH C. KoNDYLAKIS \\ National Centre for Marine Research, 16604 Ag. Kosmas, Helliniko, Athens, Greece
}

(Received November 26, 1996; Accepted May 2, 1997)

\begin{abstract}
To better understand the biogeochemical factors affecting seasonal variations of major Greek river water composition, multivariate analyses on four seasonal data matrices of thirteen major Greek rivers and tributaries have been applied. The main factors governing river water composition were "carbonate dissolution", which is the most important factor in spring, autumn and winter, and "pollution", which is most important in summer. Less important factors are "biological activity", which predominates during the dry seasons and "sodium chloride enrichment", which slightly influences river waters, primarily in spring, due to flushing processes. The Greek river catchments are characterized by different climatic, hydrographic, morphologic, petrographic and vegetative features and varying pollution impact. Nevertheless, biogeochemical processes controlling river composition appear to follow certain common seasonal trends, as they would be a part of an integrated ecosystem.
\end{abstract}

\section{INTRODUCTION}

Thirteen major Greek rivers and tributaries, which represent $75 \%$ of the total Greek peninsula surface runoff, were studied, from their sources or state boundaries down to their mouths, four times seasonally, during one hydrological cycle (1983-84). The rivers and tributaries are: EvrosArdas, Nestos-Arkoudoremma, Strymon-Angitis, Axios, Gallikos, Aliakmon, Sperchios, Acheloos and Louros. A total of 160 samples were collected from 42 river sites (Fig. 1) and analyzed for the following parameters: temperature, $\mathrm{pH}$, conductivity, dissolved oxygen, total hardness, calcium, magnesium, sodium, potassium, bicarbonate, sulfate, chloride, nitrate, phosphate, total suspended solids and dissolved organic carbon (DOC).

A previous study, concerning the factors controlling the water composition of the ten major Greek rivers (Skoulikidis, 1993) showed strong relationships between the climate of river catchments and the mean annual river water composition of the major Greek rivers. This is because climate controls chemical weathering and catchment hydrology which are strongly influencing mean river water composition. Other studies (Skoulikidis, 1990, 1991), based on cluster analyses which were performed on seasonal and spatial samples for each river separately, indicate that, in general, seasonal differences in river water composition are more important than spatial differences. Mean annual river water composition results from its intra-annual variations along the river's course. Since Greek rivers exhibit dramatic intraannual hydrological, and thus hydrochemical variations (Skoulikidis, 1990) affecting and restricting the surface water uses, the aim of the present article is to identify seasonal trends in the factors affecting the composition of Greek rivers, conceived as an integrated system.

The application of multivariate statistical techniques makes possible the simultaneous investigation of the relations between numerous variables of a data matrix. In particular, for the evaluation of hydrochemical data, that combine large numbers of parameters and samples, factor 


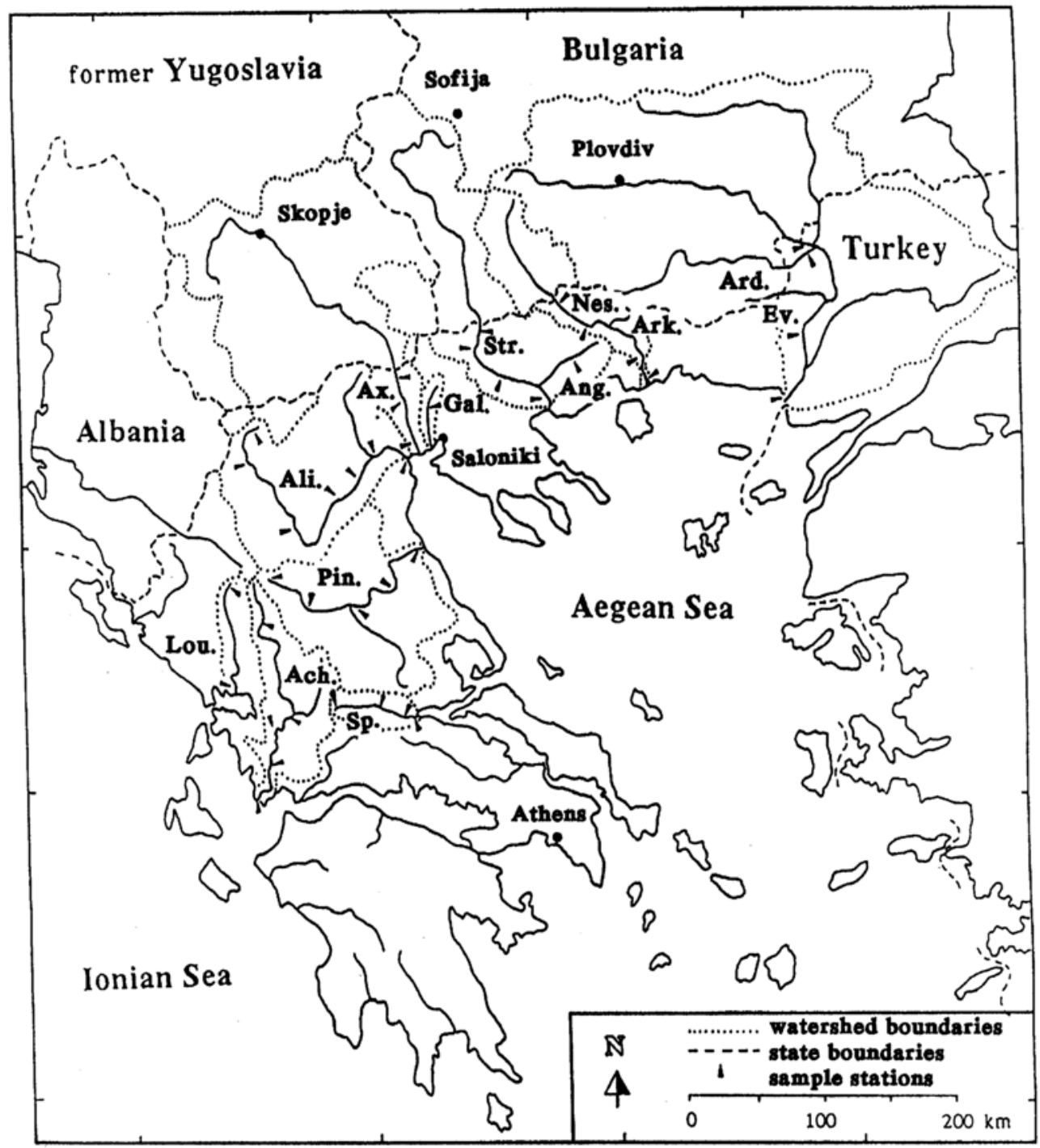

Fig. 1. Greek river catchments and sample stations. Ev. $=$ Evros, Ard. $=$ Ardas, Nes. $=$ Nestos, Ark. $=$ Arkudoremma, Str. $=$ Strymon, Ang. $=$ Angitis, Gal. $=$ Gallikos, Ax. $=$ Axios, Ali.$=$ Aliakmon, Pin.$=$ Pinios, Sp . $=$ Sperchios, Ach.$=$ Acheloos, Lou. $=$ Louros .

and cluster analyses have been successfully applied, especially for the determination of the origin of hydrochemical species (e.g., Hoetzl, 1982; Hoelting, 1982; Vegas-Vilarrubia and Rull, 1988; Briz-Kishore and Murali, 1992).

\section{METHODS}

Physicochemical parameters (temperature, $\mathrm{pH}$, conductivity) were measured in situ with portable meters (WTW). The total hardness and the major anions (bicarbonate, sulfate, chloride) were determined in a mobil laboratory with a Hach digital titrator, and dissolved oxygen was measured by Winkler titration. For the determination of total suspended solids the samples were passed through a 0.45 membran filter. The filtrates were preserved by addition of $\mathrm{HCl}$ or $\mathrm{HgCl}_{2}$ and then analyzed in 
the laboratory with a Perkin Elmer A.A.S. for calcium, magnesium, sodium and potassium, and with a Hach Spectrophotometer for sulfate, nitrate, phosphate and silicate. For the determination of dissolved organic carbon the samples were passed through glas fibre filters and then analyzed with a Carlo Erba Total Carbon Monitor via total thermal combustion. Carbon dioxide partial pressure and the saturation indices of calcite and dolomite were calculated by a computer program (Kempe, 1975a).

For each site of the examined rivers and tributaries, seasonal mean values of 22 parameters were estimated, which resulted in the formation of four data matrices, each of dimension $22 \times 13$ (Appendix, Tables A1(a)-(d)). In order to achieve a better understanding of the seasonal variation of the biogeochemical processes and factors controlling river water composition, multivariate statistical analyses (factor and cluster analyses) were performed for each seasonal data matrix separately.

The analysis of the relationships between the descriptors (variables or attributes that describe or compare the objects of a study) of a multidimensional data matrix is often carried out by factor analysis. The primary aim of factor analysis is to account for the covariance between the descriptors. To do this, factor analysis assumes that the observed descriptors are linear combinations of hypothetical underlying variables (or factors). As a result, factor analysis represents the covariance structure of the descriptors in terms of a hypothetical causal model (observed descriptors caused by the underlying factors).

Cluster analysis may be used in order to identify objects sufficiently similar to be grouped in the same set, and simultaneously to distinguish or separate groups of objects.

In the present study $\mathrm{R}$-mode technique factor and cluster analyses were carried out, using a computer program of Wong (1982). R-mode technique applies models of multidimensional analysis in the association matrix (descriptors $\times$ descriptors) which is formed from the basic data matrix (descriptors $\times$ objects).

\section{Results AND Discussion}

Factor analysis is used here to reveal the major biogeochemical processes and factors affecting Greek river water composition for each season separately (Tables $1(\mathrm{a})-(\mathrm{d})$ ). The term variance $\%$ indicates the participation of each factor in the variance of data, and it may be thought as an indication of how important a specific factor is in the deviation of data from their mean. The numbers in Tables 1(a)-(d) indicate the amount of covariance between a specific couple of a descriptor (parameter) and a factor, which may be thought as a measure of association between these two variables. The results of the cluster analysis are presented in dendrograms (Figs. 2(a)-(d)) and are also used in the explanations of seasonal trends of river water constituents, especially for the determination of entities undergoing similar seasonal variations. The numbers in river water composition type axis are the values at which the next fusion between clusters is made and there is a correspondence value in the similarities axis. The numbers in the similarities axis indicate a relative similarity measure between the river water composition types.

Seasonal variations of major Greek rivers composition and their interpretation

Tables A1(a)-(d) in Appendix present the seasonal composition of thirteen major Greek rivers and tributaries. These data represent means from various samples along the river courses.

Factor analyses performed on four seasonal matrices distinguish three main factors: (a) dissolution of carbonates, (b) pollution and (c) biological activity. A fourth, less important factor, comprises silicate and/or sodium chloride enrichment (see Tables 1(a)-(d)). According to their variance, and thus, according to their relative importance influencing the river composition, the factors were classified in the following categories: controlling factor, factor of major importance, factor of secondary importance and factor of minor importance (see Table 2). The cluster analyses on 
Table 1(a). Common factor analysis (R-mode) of Greek rivers in spring

\begin{tabular}{|c|c|c|c|c|}
\hline & \multicolumn{4}{|c|}{ Rotated Factor Matrix } \\
\hline & $\begin{array}{c}\text { Factor } 1 \\
\text { Dissolution of carbonates }\end{array}$ & $\begin{array}{l}\text { Factor } 2 \\
\text { Pollution }\end{array}$ & $\begin{array}{c}\text { Factor } 3 \\
\text { Biological activity } \\
\end{array}$ & $\begin{array}{c}\text { Factor } 4 \\
\mathrm{NaCl} \text { enrichment }\end{array}$ \\
\hline Variance (\%) & 46.5 & 19.9 & 9.2 & 8.2 \\
\hline $\mathrm{Tw}$ & 0.55 & & & 0.56 \\
\hline $\mathrm{pH}$ & 0.60 & & 0.72 & \\
\hline TH & 0.99 & & & \\
\hline Cond. & 0.92 & & & \\
\hline $\begin{array}{l}\mathrm{Ca}^{2+} \\
\mathrm{Mg}^{2+}\end{array}$ & $\begin{array}{l}0.95 \\
0.88\end{array}$ & & & \\
\hline $\mathrm{Na}^{+}$ & 0.88 & & 0.51 & 0.60 \\
\hline $\mathrm{K}^{+}$ & & 0.84 & & \\
\hline $\mathrm{HCO}_{2-}^{-}$ & 0.98 & & & \\
\hline $\begin{array}{l}\mathrm{SO}_{4}{ }^{2-} \\
\mathrm{Cl}^{-}\end{array}$ & & 0.72 & & 0.92 \\
\hline $\begin{array}{l}\mathrm{Cl}^{-}- \\
\mathrm{NO}_{3}^{-}\end{array}$ & 0.49 & 0.78 & & \\
\hline $\mathrm{PO}_{4}^{3-}$ & & 0.66 & & \\
\hline TDS & 0.93 & & & \\
\hline $\mathrm{SiO}_{2}$ & & & 0.49 & -0.63 \\
\hline DOC & & 0.76 & 0.43 & \\
\hline $\mathrm{P}_{\mathrm{CO}_{2}}$ & & & -0.83 & \\
\hline $\mathrm{SI}_{\text {cal }}$ & 0.78 & & 0.50 & \\
\hline $\mathrm{SI}_{\text {dol }}$ & 0.82 & & 0.52 & \\
\hline TSS & & 0.73 & & \\
\hline $\begin{array}{l}\mathrm{O}_{2}{ }^{2-} \mathrm{SO}_{4}{ }^{-1} \mathrm{Cl}^{-} \\
\text {- }\end{array}$ & 0.57 & 0.69 & & 0.45 \\
\hline
\end{tabular}

Table 1(b). Common factor analysis (R-mode) of Greek rivers in summer

\begin{tabular}{|c|c|c|c|c|}
\hline & \multicolumn{4}{|c|}{ Rotated Factor Matrix } \\
\hline & $\begin{array}{l}\text { Factor } 1 \\
\text { Pollution } \\
\end{array}$ & $\begin{array}{c}\text { Factor } 2 \\
\text { Dissolution of carbonates }\end{array}$ & Factor 3 & $\begin{array}{c}\text { Factor } 4 \\
\text { Biological activity }\end{array}$ \\
\hline Variance $(\%)$ & 48.9 & 20 & 11.4 & 9.1 \\
\hline Tw & & & & -0.78 \\
\hline $\mathrm{pH}$ & & & & -0.93 \\
\hline TH & & 0.99 & & \\
\hline Cond. & & 0.89 & & \\
\hline $\mathrm{Ca}^{2+}$ & & 0.97 & & \\
\hline $\mathrm{Mg}^{2+}$ & & 0.83 & & \\
\hline $\begin{array}{l}\mathrm{Na}^{+} \\
\mathrm{K}^{+}\end{array}$ & $\begin{array}{l}0.90 \\
0.86\end{array}$ & & & \\
\hline $\mathrm{HCO}_{3}^{-}$ & & 0.99 & & \\
\hline $\mathrm{SO}_{4}^{2-}$ & 0.85 & & & \\
\hline $\mathrm{Cl}^{-}$ & 0.73 & & & \\
\hline $\mathrm{NO}_{3}^{-}$ & 0.76 & & & \\
\hline $\mathrm{PO}_{4}{ }^{3-}$ & & & & \\
\hline TDS & & 0.91 & & \\
\hline $\mathrm{SiO}_{2}$ & & & 0.87 & \\
\hline $\begin{array}{l}\mathrm{DOC} \\
\mathrm{P}_{\mathrm{CO}_{2}}\end{array}$ & & & & 0.91 \\
\hline $\mathrm{SI}_{\text {cal }}$ & & 0.63 & & -0.73 \\
\hline $\mathrm{SI}_{\mathrm{dol}}$ & & 0.70 & & -0.64 \\
\hline TSS & 0.69 & & 0.56 & \\
\hline $\mathrm{O}_{2}{ }^{2-}$ & 0.53 & & & -0.51 \\
\hline $\mathrm{SO}_{4}{ }^{2-1} / \mathrm{Cl}^{-}$ & & & 0.75 & \\
\hline
\end{tabular}


Table 1(c). Common factor analysis (R-mode) of Greek rivers in autumn

\begin{tabular}{|c|c|c|c|c|}
\hline & \multicolumn{4}{|c|}{ Rotated Factor Matrix } \\
\hline & $\begin{array}{c}\text { Factor } 1 \\
\text { Dissolution of carbonates, } \\
\mathrm{NaCl} \text { enrichment }\end{array}$ & $\begin{array}{c}\text { Factor } 2 \\
\text { Pollution }\end{array}$ & $\begin{array}{c}\text { Factor } 3 \\
\text { Biological activity } \\
\text { Respiration }\end{array}$ & $\begin{array}{c}\text { Factor } 4 \\
\text { Biological activity } \\
\text { Photosynthesis }\end{array}$ \\
\hline Variance (\%) & 45.9 & 18 & 14.6 & 8.3 \\
\hline $\mathrm{Tw}$ & & & -0.46 & 0.77 \\
\hline $\mathrm{pH}$ & & & -0.95 & \\
\hline TH & 0.98 & & & \\
\hline Cond. & 0.91 & & & \\
\hline $\mathrm{Ca}^{2+}$ & 0.95 & & & \\
\hline $\mathrm{Mg}^{2+}$ & 0.81 & & & \\
\hline $\mathrm{Na}^{+}$ & 0.53 & -0.60 & & \\
\hline $\mathrm{K}^{+}$ & & -0.79 & & \\
\hline $\mathrm{HCO}_{3}^{-}$ & 0.88 & & & \\
\hline $\mathrm{SO}_{4}^{2-}$ & & -0.87 & & \\
\hline $\mathrm{Cl}^{-}$ & 0.66 & -0.43 & & \\
\hline $\mathrm{NO}_{3}^{-}$ & 0.49 & -0.78 & & \\
\hline $\mathrm{PO}_{4}^{3-}$ & & -0.62 & & \\
\hline TDS & 0.94 & & & \\
\hline $\mathrm{SiO}_{2}$ & & -0.64 & & \\
\hline DOC & & -0.65 & & 0.47 \\
\hline $\mathrm{P}_{\mathrm{CO}_{2}}$ & & & 0.86 & \\
\hline $\mathrm{SI}_{\mathrm{cal}}$ & 0.58 & & -0.76 & \\
\hline $\mathrm{SI}_{\mathrm{dol}}$ & 0.66 & & -0.70 & \\
\hline TSS & & -0.83 & & \\
\hline $\mathrm{O}_{2}$ & & & & 0.94 \\
\hline $\mathrm{SO}_{4}^{2-} / \mathrm{Cl}^{-}$ & & -0.91 & & \\
\hline
\end{tabular}

Table $1(d)$. Common factor analysis (R-mode) of Greek rivers in winter

\begin{tabular}{|c|c|c|c|c|}
\hline & \multicolumn{4}{|c|}{ Rotated Factor Matrix } \\
\hline & $\begin{array}{c}\text { Factor } 1 \\
\text { Dissolution of carbonates }\end{array}$ & $\begin{array}{c}\text { Factor } 2 \\
\text { Biological activity }\end{array}$ & $\begin{array}{l}\text { Factor } 3 \\
\text { Pollution }\end{array}$ & $\begin{array}{c}\text { Factor } 4 \\
\text { Weathering of silicates }\end{array}$ \\
\hline Variance (\%) & 45 & 15.8 & 13.9 & 8.3 \\
\hline $\mathrm{Tw}$ & 0.68 & & & \\
\hline $\mathrm{pH}$ & & 0.92 & & \\
\hline TH & 0.97 & & & \\
\hline Cond. & 0.85 & & -0.50 & \\
\hline $\mathrm{Ca}^{2+}$ & 0.93 & & & \\
\hline $\mathrm{Mg}^{2+}$ & 0.81 & & & \\
\hline $\mathrm{Na}^{+}$ & & & -0.95 & \\
\hline $\mathrm{K}^{+}$ & & & -0.87 & \\
\hline $\mathrm{HCO}_{3}^{-}$ & 0.98 & & & \\
\hline $\mathrm{SO}_{4}^{2-}$ & & & -0.92 & \\
\hline $\mathrm{Cl}^{-}$ & & & -0.75 & \\
\hline $\mathrm{NO}_{3}^{-}$ & & & -0.77 & \\
\hline $\mathrm{PO}_{4}^{3-}$ & & & -0.65 & \\
\hline TDS & 0.89 & & & \\
\hline $\mathrm{SiO}_{2}$ & & & & 0.92 \\
\hline DOC & & & & \\
\hline $\mathrm{P}_{\mathrm{CO}_{2}}$ & & -0.95 & & \\
\hline $\mathrm{SI}_{\mathrm{cal}}$ & 0.75 & 0.61 & & \\
\hline $\mathrm{SI}_{\text {dol }}$ & 0.82 & 0.54 & & \\
\hline TSS & & 0.63 & & \\
\hline & & 0.55 & & \\
\hline $\mathrm{SO}_{4}^{2-} / \mathrm{Cl}^{-}$ & & & & 0.55 \\
\hline
\end{tabular}

Tw: water temperature, TH: total hardness, Cond.: conductivity, TDS: total dissolved solids, TSS: total suspended solids, $\mathrm{P}_{\mathrm{CO}_{2}}$ : carbon dioxide partial pressure, $\mathrm{SI}_{\text {cal }}$ : calcite saturation index, $\mathrm{SI}_{\text {dol }}$ : dolomite saturation index. 


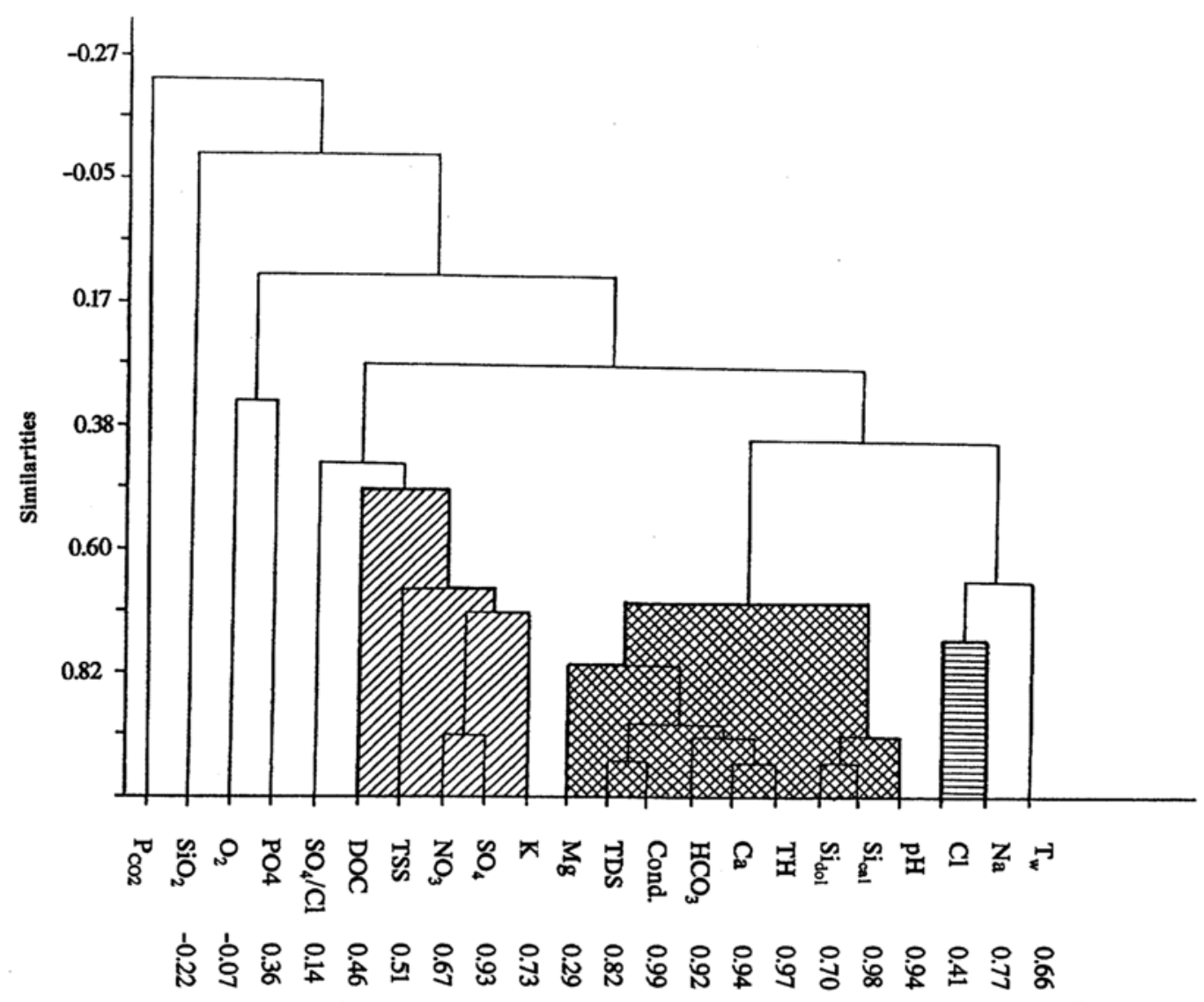

pollution

carbonate dissolution

sodium chloride flushing

Fig. 2(a). Cluster analysis of Greek river composition in spring.

the seasonal matrices may illustrate similarly four major groups of parameters (Figs. 2(a)-(d)).

In the remaining part of this section, the seasonal trends of the biogeochemical processes controlling river water composition in different seasons will be discussed. For this purpose, the results of the multivariate analysis and the existing knowledge on biogeochemical processes governing Greek rivers will be used:

Carbonate dissolution Dissolution of limestones and dolomites enriches river water with alkali earth and bicarbonate ions. Due to the predominance of carbonate rocks in Greek river catchments and of calcium/magnesium carbonates in river sediments and riverine suspended matter
(Skoulikidis, 1990), Greek rivers are marked by high concentrations in these ions. Specifically, in average $78 \%$, by weight, of Greek rivers dissolved inorganic constituents are composed of calcium, magnesium and bicarbonate. These ions reach high to maximum concentrations during the dry seasons of the year (summer, autumn) (Tables A1(a)-(d)).

Multivariate analyses performed on the mean annual composition of Greek river waters indicate that "carbonate dissolution" is the controlling factor of Greek rivers hydrochemistry, indeed (Skoulikidis, 1993). The present research work reveals "carbonate dissolution" as the controlling factor of Greek rivers hydrochemistry only for spring, autumn and winter. In summer "carbonate 


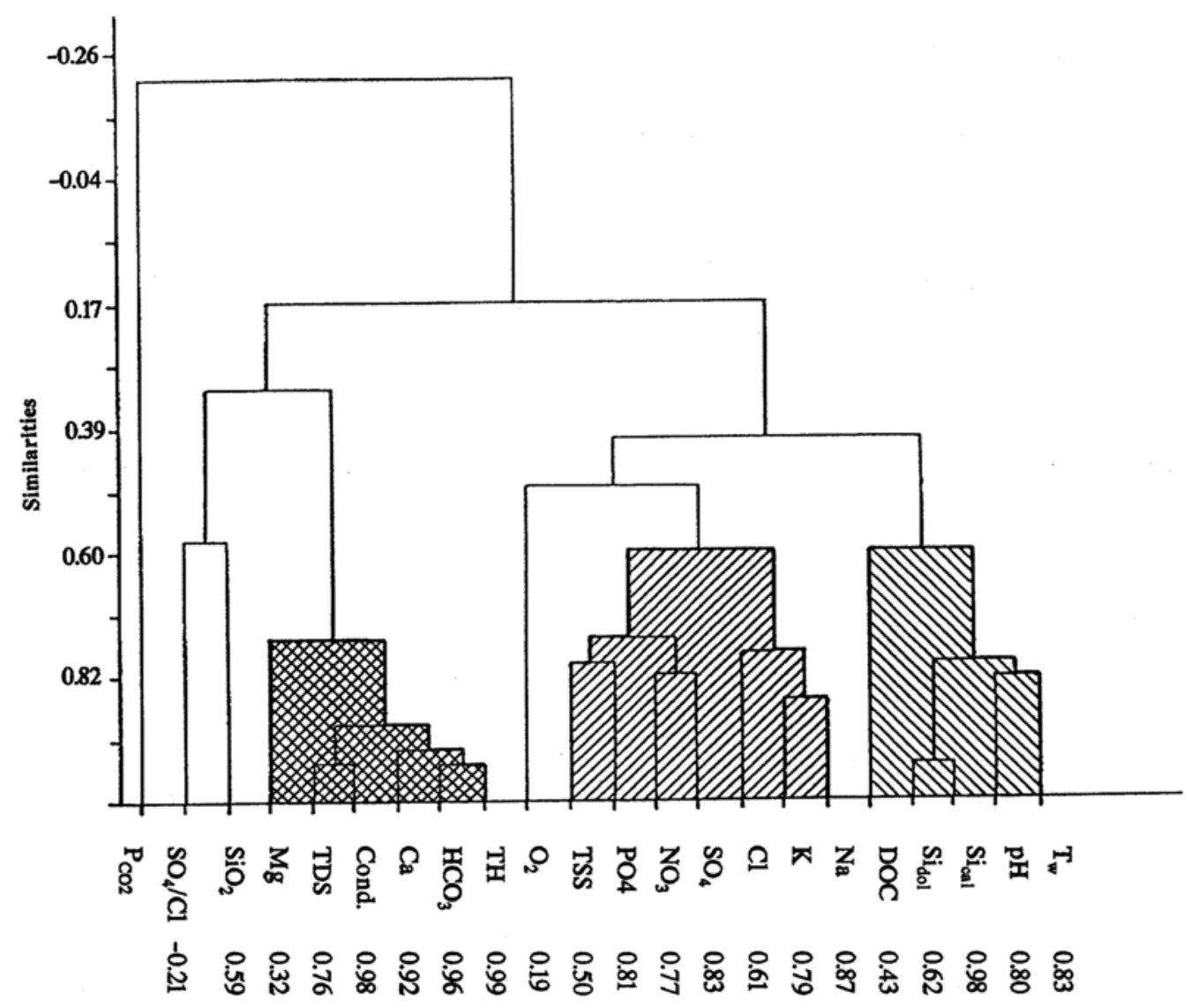

carbonate dissolution

Fig. 2(b). Cluster analysis of Greek river composition in summer.

dissolution" becomes the second important factor after the factor "pollution".

Pollution Pollution originates mainly from agriculture and sewage which contribute the main part of potassium, nitrates, phosphates, sulfates, sodium and chloride in river water (e.g., Zorbist and Stumm, 1981; Moldan, 1987; Tremblay and Cossa, 1987; Skoulikidis, 1988, 1993). In summer, "pollution", mainly originating from sewage and seasonal industries (e.g., food industries which are active during the summer period), becomes the controlling factor of Greek rivers hydrochemistry (Table 1(b)), although pollutant concentrations are low (Tables A1(a)-(d), Table
2). This may be explained that in summer river water composition is more sensitive in variations of pollution since river runoff and water volume is low. Hence, the same magnitude of variation in pollutants' input in summer causes higher impact in river hydrochemistry than in other seasons. In contrast, in winter, river composition is not sensitive in variations of pollution, although pollutants show annual maximum concentrations due to arable land flushing.

Biological activity During summer and autumn, when runoff is very low, high water temperatures and low turbidity, combined with the presence of nutrient compounds, enhance photo- 


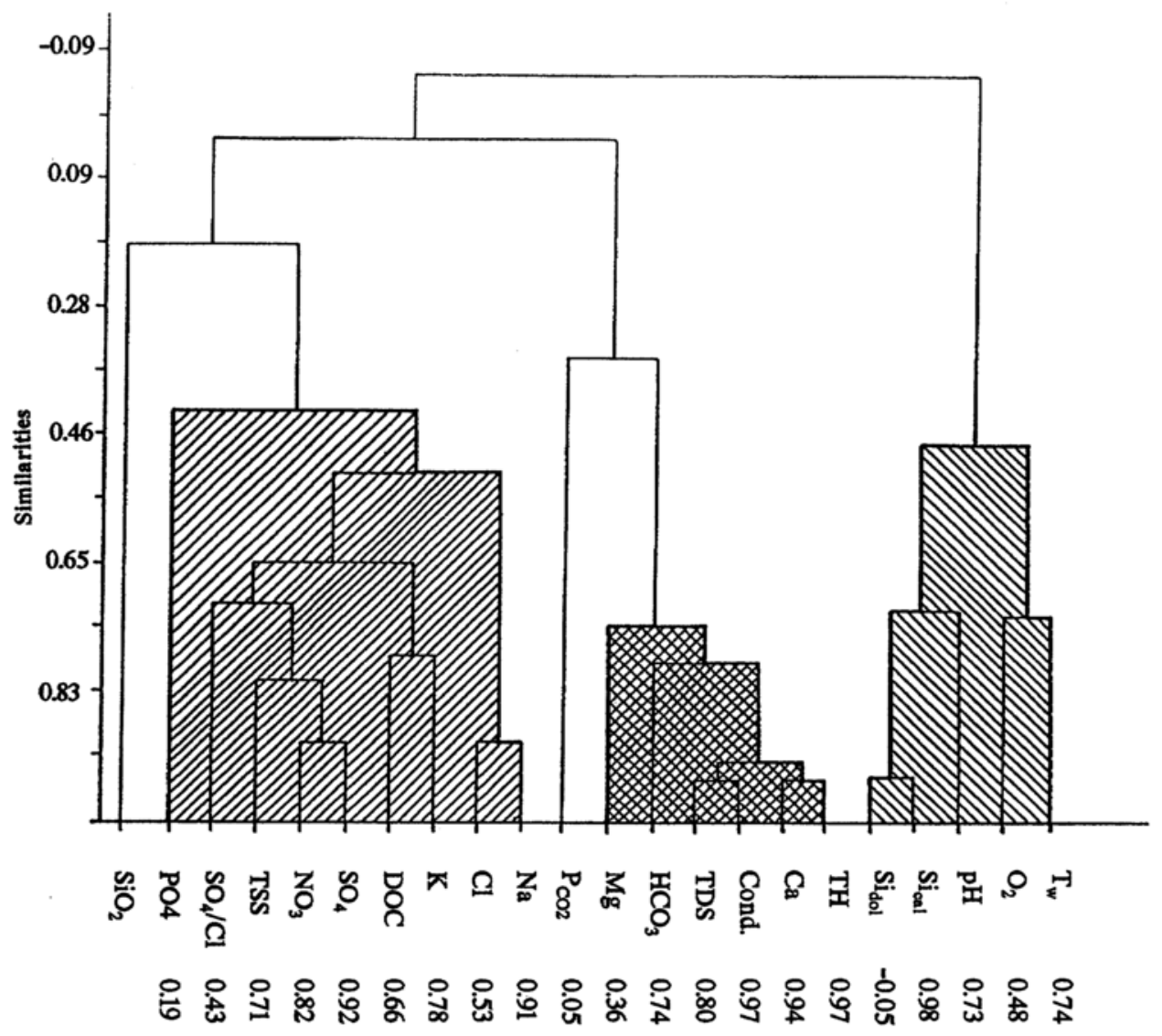

QDallution carbonate dissolution

Fig. 2(c). Cluster analysis of Greek river composition in autumn.

synthetic processes in Greek rivers. This results in nutrient depletion, $\mathrm{pH}$ increase, carbonate oversaturation and occasionally calcite precipitation (Skoulikidis, 1990). When respiration processes predominate, DOC originating from organic wastes (sewage and food industry wastes) or/and dead phytoplankton, decomposes producing carbon dioxide. This results in a possible carbonate salts dissolution (Skoulikidis, 1990).

The importance of biological activity for Greek river water composition is shown in Tables 1(a)(d) and Table 2. According to the cluster analyses (Figs. 2(a)-(d)), which provide better information on variable groupings, biological activity is clearly pronounced only during the low water period (summer and autumn) and is favored in catchments with higher water temperatures (Figs. 2(b) and (c)). In autumn Greek rivers are affected by both photosynthesis and respiration.

Enrichment with sodium chloride During the low water period the main source of sodium and chloride are probably sewage wastes (Tables 1(b) and (c), Figs. 2(b) and (c)). Another sodium chloride source, which is only expressed in autumn, by minimum runoff, is baseflow which enriches river water with major ions (Table 1(c)). Finally, these ions are carried into Greek rivers through flushing processes. During initial floodings, and when high runoff originating from precipitation and snow melting causes extended floodings in 


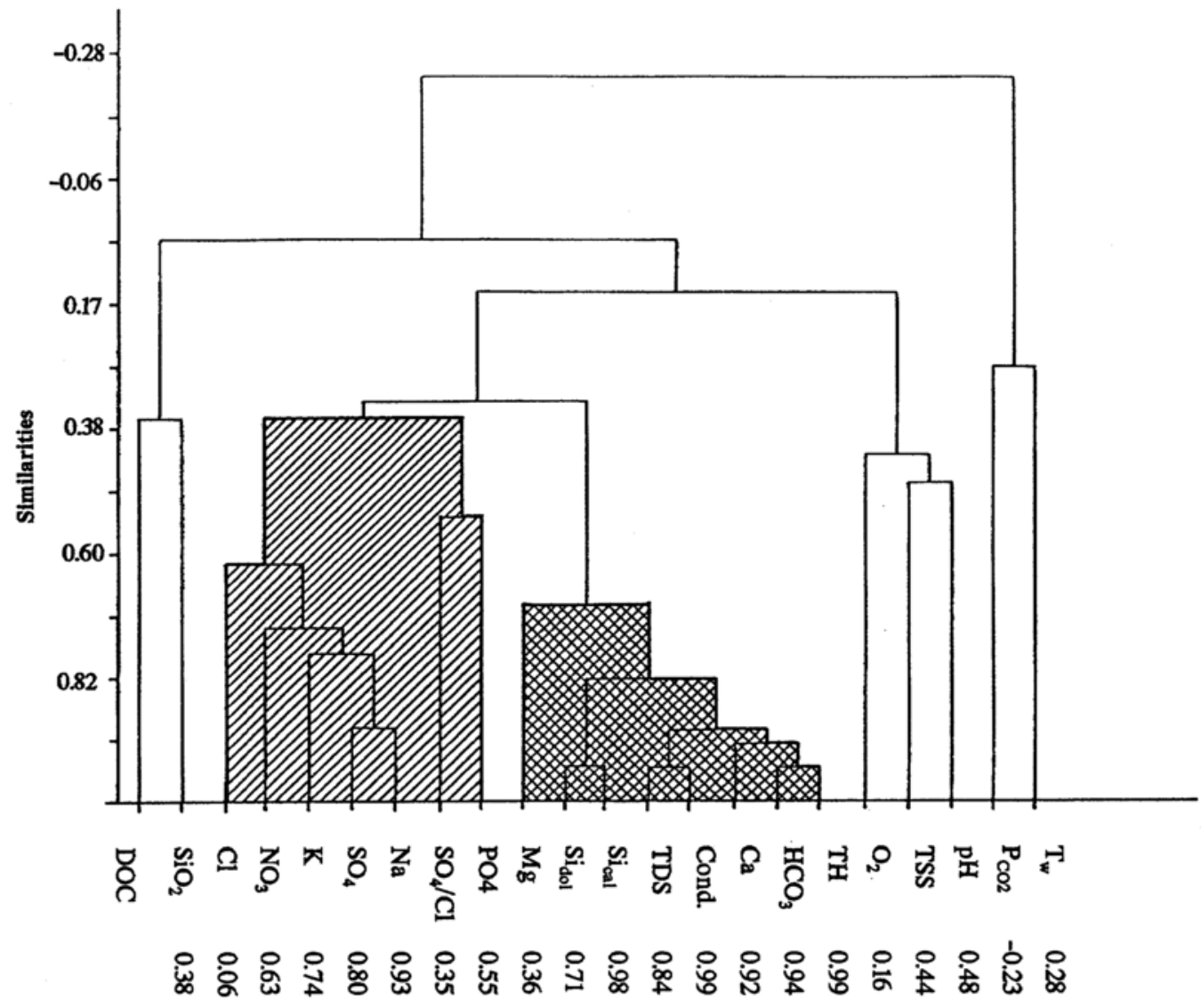

pollution $\begin{aligned} & \text { sodium chloride flushing } \\ & \text { carbonate dissolution }\end{aligned}$

Fig. 2(d). Cluster analysis of Greek river composition in winter.

river plains, soil flushing phenomena are enhanced (Edwards, 1973; Walling and Foster, 1975; Skoulikidis, 1990, 1991, 1993). As a result, sodium chloride salts, which accumulate in soil pores during the dry season of year under the semi-arid conditions of Greek plains, and additionally enhanced by agricultural activities, are leached and enriched in river waters. The results of the multivariate analyses indicate that this process is clearly pronounced in spring (Table 1(a), Fig. 2(a)), when river runoff reaches annual maximum. In winter, sodium chloride reaches the rivers also through flushing but combined with agrochemical pollutants (Table 1(d), Fig. 2(d)).
Summarized results of major seasonal variations in major Greek rivers composition

Table 2 shows the summarized results on the seasonal variations of biogeochemical processes and factors affecting Greek rivers composition. In general, biogeochemical processes appear to follow certain seasonal trends.

\section{Conclusions}

The main conclusion of this paper is the following: since the examined Greek rivers have catchments with different climatic, hydrographic, morphologic, petrographic and vegetative features 


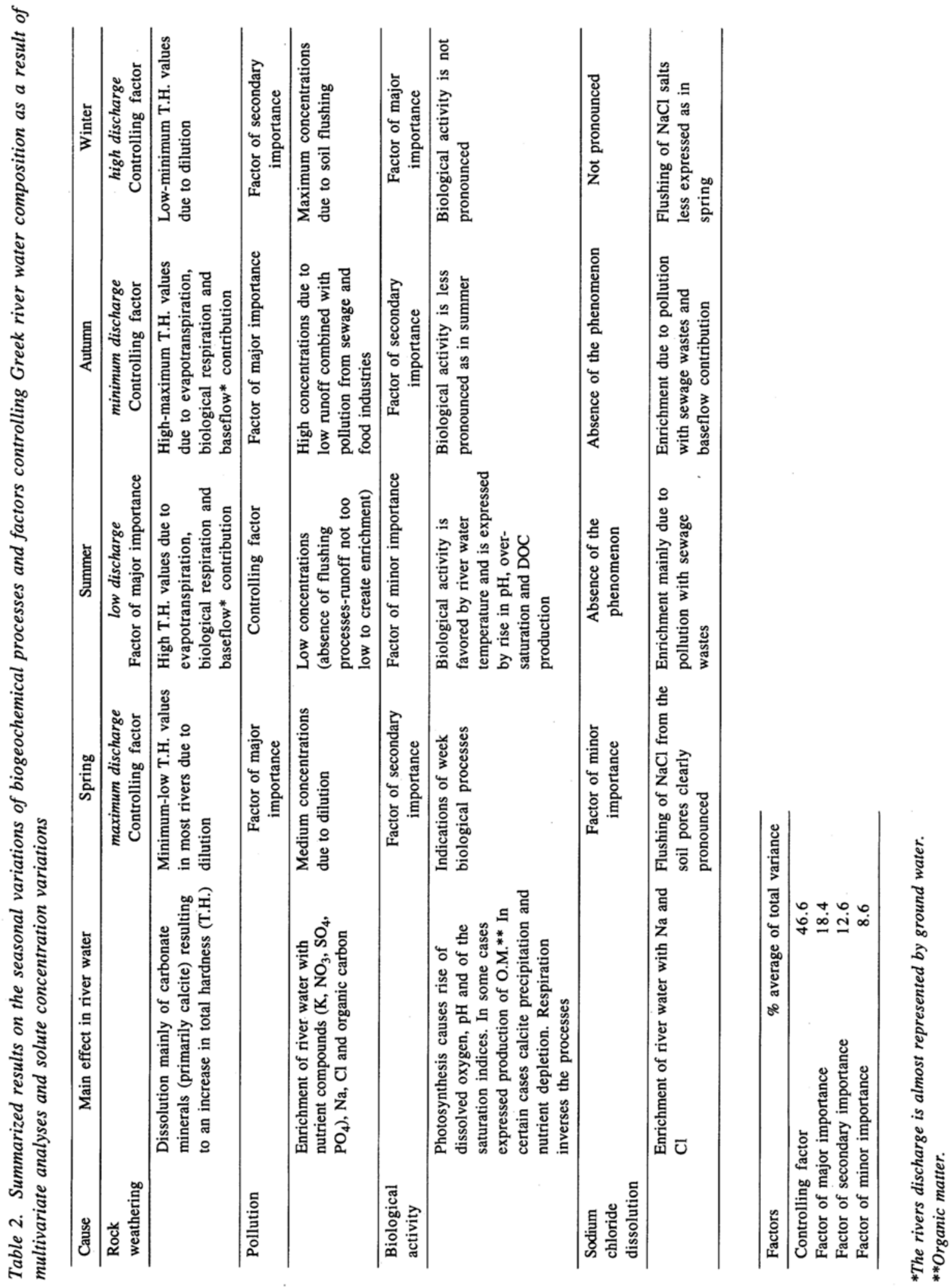


and varying pollution impact (Skoulikidis, 1990, 1993), it is of major interest and importance that biogeochemical processes affecting seasonal variations in water composition of major Greek rivers appear to follow certain common seasonal trends, as they would be a part of an integrated ecosystem. It is important for catchment management and river water protection tasks to consider that river water hydrochemistry is more strongly affected by pollution variations in summer than in the other seasons, although pollutant concentrations are generally low. However, in order to achieve a more detailed understanding of the intraannual variations in Greek rivers water composition, further research is necessary to monitor Greek river water constitution with denser time intervals.

\section{REFERENCES}

Briz-Kishore, B. H. and Murali, G. (1992) Factor analysis for revealing hydrochemical characteristics of a watershed. Environ. Geol. Water Sci. 19, 3-9.

Edwards, A. M. (1973) The variation of dissolved constituents with discharge in some Norfolk rivers. J. Hydrology 18, 219-242.

Hoelting, B. (1982) Geohydrochemie in Bundsandstein der Bundesrepublik Deutschland-Statistische Auswerung von Grundwasseranalysen. DVWK Schriften, 54, Auswerung hydrochemischer Daten, Komissionsvertrieb Verlag Paul Parey, Hamburg, Berlin, 87-188.

Hoetzl, H. (1982) Statistische Methoden zur Auswerung hydrochemischer Daten. DVWK Schriften, 54, Auswerung hydrochemischer Daten, Komissionsvertrieb Verlag Paul Parey, Hamburg, Berlin, 1-69.

Kempe, S. (1975a). A computer program for hydrochemical problems in karstic water. Ann. Speleol. 30, 699-702.

Moldan, B. (1987) Sources of seven chemical elements in the water runoff in Bohemia. Transport of Carbon and Minerals in Major World Rivers (Degens, E.
T. and Kempe, S., eds.), Mitt. Geol.-Palaeont. Inst. Univ. Hamburg, SCOPE/UNEP Sonderband, 64, 375385.

Skoulikidis, N. (1988) Biogeochemistry of the major Greek rivers. Heavy Metals in the Hydrological Cycle (Astruc, M. and Lester, J. N., eds.), 687-694, Selper Ltd., London.

Skoulikidis, N. (1990) Biogeochemie der groessten Fluesse Griechenlands. Ph.D. Thesis, University of Hamburg, Inst. of Geology and Paleontology, 313 pp.

Skoulikidis, N. (1991) Parameters influencing the chemistry and pollution of river water-Characteristic example the river Nestos. 2nd. Conf. of Environmental Science and Technology (Lekas, Th., ed.), 600-611, Molyvos, Mytilini, Greece.

Skoulikidis, N. (1993) Significance evaluation of factors controlling river water composition. Environ. Geol. 22, 178-185.

Tremblay, G. H. and Cossa, D. (1987) Major ion composition of the St. Lawrence river: Variations since the start of the Industrialization. Transport of Carbon and Minerals in Major World Rivers (Degens, E. T. and Kempe, S., eds.), Mitt. Geol.-Palaeont. Inst. Univ. Hamburg, SCOPE/UNEP Sonderband, 64, 289293.

Vegas-Vilarrubia, T. and Rull, V. (1988) A multivariate statistical classification of Venezuelan blackwater rivers. Mitt. Geol. Palaeont. Inst. Univ. Hamburg, SCOPE/UNEP Sonderband, 66, 51-61.

Walling, D. E. and Foster, I. D. L. (1975) Variations in the natural chemical concentration of river water during flood flows, and the lag effect: some further comments. J. Hydrology. 26, 237-244.

Wong, H. K. (1982) A computer program for multivariate statistical analysis. University of Hamburg, Inst. of Geology and Paleontology.

Zorbist, J. and Stumm, W. (1981) Chemical dynamics of the Rhine catchment area in Switzerland, extrapolation to the "pristine" Rhine river input to the ocean. River Inputs to the Ocean System (Martin, J. M., Burton, J. D. and Eisma, D., eds.), Proceedings of SCOR/ACMRR/ECOR/IAHS/UNESCO/CMG/IABO/ IAPSO Review and Workshop, FAO Headquarters, Rome, 26-30 March 1979, 52-63. 
APPENDIX

Table Al(a). Average composition of Greek river waters in spring

\begin{tabular}{|c|c|c|c|c|c|c|c|c|c|c|c|}
\hline \multirow[t]{2}{*}{ River } & \multirow{2}{*}{$\begin{array}{l}\mathrm{Tw} \\
\left({ }^{\circ} \mathrm{C}\right)\end{array}$} & $\mathrm{pH}$ & \multirow{2}{*}{$\begin{array}{l}\text { Cond. } \\
(\mathrm{mS} / \mathrm{cm})\end{array}$} & \multirow[t]{2}{*}{ TH } & $\mathrm{Ca}$ & $\mathrm{Mg}$ & $\mathrm{Na}$ & $\mathrm{K}$ & $\mathrm{HCO}_{3}$ & $\mathrm{SO}_{4}$ & $\mathrm{Cl}$ \\
\hline & & & & & \multicolumn{7}{|c|}{$(\mathrm{mval} / \mathrm{l})$} \\
\hline Evros & 13.7 & 8.42 & 0.42 & 2.83 & 2.20 & 0.63 & 1.12 & 0.14 & 2.26 & 1.15 & 0.48 \\
\hline Ardas & 13.0 & 8.16 & 0.28 & 2.04 & 1.67 & 0.37 & 0.52 & 0.07 & 1.64 & 0.51 & 0.31 \\
\hline Nestos & 10.5 & 7.99 & 0.20 & 1.70 & 1.43 & 0.27 & 0.26 & 0.07 & 1.55 & 0.26 & 0.12 \\
\hline Arkudorema & 8.0 & 7.55 & 0.11 & 0.92 & 0.84 & 0.08 & 0.17 & 0.04 & 0.88 & 0.13 & 0.14 \\
\hline Strymon & 13.0 & 8.36 & 0.38 & 3.08 & 2.38 & 0.70 & 0.64 & 0.08 & 2.78 & 0.61 & 0.32 \\
\hline Angitis & 15.0 & 7.91 & 0.58 & 5.60 & 4.47 & 1.13 & 0.35 & 0.05 & 4.62 & 0.98 & 0.31 \\
\hline Gallikos & 14.5 & 8.32 & 0.39 & 2.10 & 1.41 & 0.69 & 1.74 & 0.07 & 2.80 & 0.62 & 0.45 \\
\hline Axios & 10.0 & 8.29 & 0.38 & 3.07 & 2.49 & 0.58 & 0.66 & 0.09 & 2.84 & 0.54 & 0.35 \\
\hline Aliakmon & 10.3 & 8.62 & 0.42 & 4.05 & 2.61 & 1.44 & 0.28 & 0.04 & 3.86 & 0.34 & 0.16 \\
\hline Pinios & 11.5 & 8.46 & 0.40 & 4.01 & 2.68 & 1.33 & 0.30 & 0.03 & 3.78 & 0.32 & 0.19 \\
\hline Sperchios & 12.7 & 8.50 & 0.39 & 3.85 & 3.18 & 0.66 & 0.35 & 0.04 & 3.40 & 0.55 & 0.24 \\
\hline Sperchios springs & 8.0 & 6.70 & 0.10 & 0.91 & 0.72 & 0.19 & 0.17 & 0.03 & 0.84 & 0.16 & 0.16 \\
\hline Acheloos & 13.5 & 8.27 & 0.35 & 3.05 & 2.49 & 0.57 & 0.66 & 0.04 & 2.93 & 0.26 & 0.52 \\
\hline Mean & 11.8 & 8.12 & 0.34 & 2.86 & 2.20 & 0.66 & 0.55 & 0.06 & 2.63 & 0.49 & 0.29 \\
\hline Min. & 8.0 & 6.70 & 0.10 & 0.91 & 0.72 & 0.08 & 0.17 & 0.03 & 0.84 & 0.13 & 0.12 \\
\hline Max. & 15.0 & 8.62 & 0.58 & 5.60 & 4.47 & 1.44 & 1.74 & 0.14 & 4.62 & 1.15 & 0.52 \\
\hline ST. DEV. & 2.30 & 0.51 & 0.13 & 1.34 & 1.01 & 0.42 & 0.44 & 0.03 & 1.16 & 0.30 & 0.13 \\
\hline
\end{tabular}

Table Al(a). (continued)

\begin{tabular}{|c|c|c|c|c|c|c|c|c|c|c|}
\hline \multirow[t]{2}{*}{ River } & $\mathrm{NO}_{3}$ & $\mathrm{PO}_{4}$ & $\mathrm{SiO}_{2}$ & DOC & TDS & TSS & \multirow{2}{*}{$\begin{array}{c}\mathrm{O}_{2} \\
\text { (\% sat) }\end{array}$} & \multirow{2}{*}{$\begin{array}{c}\mathrm{P}_{\mathrm{CO}_{2}} \\
\text { (ppmv) }\end{array}$} & \multirow[t]{2}{*}{$\mathrm{SI}_{\text {cal }}$} & \multirow[t]{2}{*}{$\mathrm{SI}_{\mathrm{dol}}$} \\
\hline & \multicolumn{6}{|c|}{$(\mathrm{mg} / \mathrm{l})$} & & & & \\
\hline Evros & 10.23 & 0.76 & 8.40 & 3.21 & 8.17 & 34.00 & 111 & 951 & 0.97 & 0.23 \\
\hline Ardas & 4.27 & 1.50 & 13.40 & 2.18 & 5.30 & 16.00 & 107 & 541 & 0.04 & -0.27 \\
\hline Nestos & 3.30 & 0.27 & 12.47 & 2.38 & 4.00 & 17.20 & 103 & 771 & -0.23 & -0.60 \\
\hline Arkudorema & 1.32 & 0.19 & 12.53 & 2.10 & 2.25 & 3.00 & 102 & 1171 & -1.14 & -1.67 \\
\hline Strymon & 4.33 & 0.26 & 12.95 & 1.68 & 7.59 & 21.6 & 99 & 624 & 0.52 & 0.27 \\
\hline Angitis & 7.48 & 0.19 & 6.58 & 1.66 & 12.04 & 8.80 & 101 & 2661 & 0.62 & 0.35 \\
\hline Gallikos & 3.96 & 0.19 & 13.31 & 2.94 & 7.85 & 3.66 & 93 & 634 & 0.35 & 0.21 \\
\hline Axios & 4.40 & 0.55 & 11.24 & 1.51 & 8.81 & 9.50 & 100 & 665 & 0.51 & 0.18 \\
\hline Aliakmon & 2.91 & 0.08 & 10.25 & 1.18 & 8.83 & 8.25 & 105 & 406 & 0.97 & 0.83 \\
\hline Pinios & 3.95 & 0.17 & 12.93 & 1.27 & 8.69 & 10.70 & 98 & 625 & 0.82 & 0.67 \\
\hline Sperchios & 2.68 & 0.05 & 8.28 & 0.50 & 8.47 & 21.7 & 99 & 607 & 0.82 & 0.49 \\
\hline Sperchios springs & 1.00 & 0.20 & 10.03 & 0.34 & 2.29 & 1.40 & 98 & 7941 & -2.08 & -2.38 \\
\hline Acheloos & 3.08 & 0.02 & 4.64 & 0.72 & 7.20 & 3.47 & 111 & 806 & 0.56 & 0.25 \\
\hline Mean & 4.07 & 0.34 & 10.54 & 1.67 & 7.04 & 12.25 & 102.8 & 1416 & 0.21 & -0.11 \\
\hline Min. & 1.00 & 0.02 & 4.64 & 0.34 & 2.25 & 1.40 & 93.0 & 406 & -2.08 & -2.38 \\
\hline Max. & 10.23 & 1.50 & 13.40 & 3.21 & 12.04 & 34.0 & 111.0 & 7941 & 0.97 & 0.83 \\
\hline ST. DEV. & 2.44 & 0.40 & 2.83 & 0.88 & 2.83 & 9.49 & 5.3 & 2042 & 0.90 & 0.93 \\
\hline
\end{tabular}


Table Al(b). Average composition of Greek river waters in summer

\begin{tabular}{|c|c|c|c|c|c|c|c|c|c|c|c|}
\hline \multirow[t]{2}{*}{ River } & \multirow{2}{*}{$\begin{array}{l}\mathrm{Tw} \\
\left({ }^{\circ} \mathrm{C}\right)\end{array}$} & $\mathrm{pH}$ & \multirow{2}{*}{$\begin{array}{l}\text { Cond. } \\
(\mathrm{mS} / \mathrm{cm})\end{array}$} & \multirow[t]{2}{*}{ TH } & $\mathrm{Ca}$ & $\mathrm{Mg}$ & $\mathrm{Na}$ & $\mathrm{K}$ & $\mathrm{HCO}_{3}$ & $\mathrm{SO}_{4}$ & $\mathrm{Cl}$ \\
\hline & & & & & \multicolumn{7}{|c|}{ (mval/l) } \\
\hline Evros & 25.6 & 8.64 & 0.57 & 3.62 & 2.76 & 0.85 & 1.75 & 0.15 & 3.17 & 1.45 & 0.70 \\
\hline Ardas & 27.0 & 8.56 & 0.37 & 2.6 & 2.17 & 0.43 & 0.61 & 0.06 & 2.08 & 0.56 & 0.53 \\
\hline Nestos & 23.2 & 8.20 & 0.27 & 2.58 & 2.33 & 0.25 & 0.3 & 0.05 & 2.39 & 0.27 & 0.18 \\
\hline Arkudorema & 20.0 & 8.25 & 0.15 & 1.38 & 1.3 & 0.08 & 0.17 & 0.05 & 1.3 & 0.13 & 0.14 \\
\hline Strymon & 24.5 & 8.2 & 0.41 & 3.97 & 3.24 & 0.73 & 0.44 & 0.07 & 3.77 & 0.38 & 0.29 \\
\hline Angitis & 18.0 & 7.8 & 0.50 & 4.72 & 3.75 & 0.97 & 0.35 & 0.04 & 4.60 & 0.16 & 0.27 \\
\hline Gallikos & 25.0 & 8.0 & 0.59 & 4.82 & 3.80 & 1.02 & 1.39 & 0.09 & 5.0 & 0.55 & 0.71 \\
\hline Axios & 20.7 & 8.25 & 0.44 & 3.49 & 2.93 & 0.57 & 0.55 & 0.08 & 3.12 & 0.53 & 0.54 \\
\hline Aliakmon & 19.6 & 8.43 & 0.42 & 4.06 & 2.62 & 1.44 & 0.25 & 0.04 & 3.80 & 0.33 & 0.19 \\
\hline Pinios & 20.6 & 8.10 & 0.50 & 4.84 & 3.33 & 1.57 & 0.38 & 0.05 & 4.74 & 0.32 & 0.25 \\
\hline Sperchios & 21.0 & 8.19 & 0.61 & 5.87 & 4.44 & 1.42 & 0.52 & 0.04 & 5.34 & 0.83 & 0.42 \\
\hline Sperchios springs & 9.5 & 7.10 & 0.13 & 1.12 & 0.80 & 0.32 & 0.17 & 0.01 & 1.04 & 0.11 & 0.15 \\
\hline Acheloos & 20.3 & 8.26 & 0.34 & 2.69 & 2.43 & 0.26 & 0.63 & 0.04 & 2.56 & 0.22 & 0.55 \\
\hline Mean & 21.15 & 8.15 & 0.40 & 3.52 & 2.76 & 0.76 & 0.58 & 0.06 & 3.30 & 0.45 & 0.38 \\
\hline Min. & 9.50 & 7.10 & 0.13 & 1.12 & 0.80 & 0.08 & 0.17 & 0.01 & 1.04 & 0.11 & 0.14 \\
\hline Max. & 27.00 & 8.64 & 0.61 & 5.87 & 4.44 & 1.57 & 1.75 & 0.15 & 5.34 & 1.45 & 0.71 \\
\hline ST. DEV. & 4.42 & 0.38 & 0.15 & 1.40 & 1.00 & 0.50 & 0.47 & 0.03 & 1.39 & 0.36 & 0.21 \\
\hline
\end{tabular}

Table Al(b). (continued)

\begin{tabular}{|c|c|c|c|c|c|c|c|c|c|c|}
\hline \multirow[t]{2}{*}{ River } & $\mathrm{NO}_{3}$ & $\mathrm{PO}_{4}$ & $\mathrm{SiO}_{2}$ & DOC & TDS & TSS & \multirow{2}{*}{$\begin{array}{c}\mathrm{O}_{2} \\
\text { (\% sat) }\end{array}$} & \multirow{2}{*}{$\begin{array}{c}\mathrm{P}_{\mathrm{CO}_{2}} \\
\text { (ppmv) }\end{array}$} & \multirow[t]{2}{*}{$\mathrm{SI}_{\mathrm{cal}}$} & \multirow[t]{2}{*}{$\mathrm{SI}_{\mathrm{dol}}$} \\
\hline & \multicolumn{6}{|c|}{ (mg/l) } & & & & \\
\hline Evros & 10.19 & 1.77 & 10.57 & 2.32 & 11.04 & 39.0 & 149 & 522 & 1.04 & 0.88 \\
\hline Ardas & 7.48 & 0.29 & 10.90 & 1.38 & 6.57 & 6.0 & 138 & 321 & 0.80 & 0.54 \\
\hline Nestos & 3.27 & 0.40 & 8.71 & 1.17 & 5.86 & 8.21 & 108 & 869 & 0.50 & 0.09 \\
\hline Arkudorema & 1.21 & 0.07 & 10.40 & 0.71 & 3.19 & 4.20 & 114 & 386 & 0.05 & -0.50 \\
\hline Strymon & 2.75 & 0.21 & 10.27 & 2.28 & 8.98 & 8.00 & 116 & 1497 & 0.72 & 0.51 \\
\hline Angitis & 4.40 & 0.21 & 7.90 & 0.30 & 10.22 & 2.60 & 109 & 3613 & 0.5 & 0.25 \\
\hline Gallikos & 3.52 & 0.11 & 8.90 & 1.46 & 12.62 & 2.04 & 120 & 2742 & 0.81 & 0.61 \\
\hline Axios & 4.11 & 0.73 & 7.86 & 1.30 & 8.27 & 5.60 & 103 & 914 & 0.72 & 0.41 \\
\hline Aliakmon & 3.02 & 0.05 & 10.59 & 1.64 & 7.62 & 13.34 & 106 & 700 & 0.89 & 0.81 \\
\hline Pinios & 5.46 & 0.31 & 11.95 & 2.08 & 9.21 & 20.14 & 102 & 2539 & 0.76 & 0.69 \\
\hline Sperchios & 4.77 & 0.05 & 11.40 & 0.44 & 13.04 & 10.20 & 112 & 1646 & 0.99 & 0.79 \\
\hline Sperchios springs & 1.00 & 0.12 & 10.90 & 0.08 & 2.61 & 2.00 & 91 & 3954 & -1.54 & -1.73 \\
\hline Acheloos & 2.42 & 0.03 & 4.06 & 0.73 & 6.73 & 3.05 & 158 & 727 & 0.57 & 0.14 \\
\hline Mean & 4.12 & 0.33 & 9.57 & 1.22 & 8.15 & 9.56 & 117.4 & 1571 & 0.52 & 0.27 \\
\hline Min. & 1.00 & 0.03 & 4.06 & 0.08 & 2.61 & 2.00 & 91.0 & 321 & -1.54 & -1.73 \\
\hline Max. & 10.19 & 1.77 & 11.95 & 2.32 & 13.04 & 39.00 & 158.0 & 3954 & 1.04 & 0.88 \\
\hline ST. DEV. & 2.51 & 0.47 & 2.10 & 0.74 & 3.21 & 10.24 & 19.5 & 1246 & 0.67 & 0.70 \\
\hline
\end{tabular}

Tw: water temperature, TH: total hardness, Cond.: conductivity, TDS: total dissolved solids, TSS: total suspended solids, $\mathrm{P}_{\mathrm{CO}_{2}}$ : carbon dioxide partial pressure, $\mathrm{SI}_{\text {cal }}$ : calcite saturation index, $S I_{\text {dol }}$ : dolomite saturation index. 
Table Al(c). Average composition of Greek river waters in autumn

\begin{tabular}{|c|c|c|c|c|c|c|c|c|c|c|c|}
\hline \multirow[t]{2}{*}{ River } & \multirow{2}{*}{$\begin{array}{l}\mathrm{Tw} \\
\left({ }^{\circ} \mathrm{C}\right)\end{array}$} & $\mathrm{pH}$ & \multirow{2}{*}{$\begin{array}{l}\text { Cond. } \\
(\mathrm{mS} / \mathrm{cm})\end{array}$} & \multirow[t]{2}{*}{ TH } & $\mathrm{Ca}$ & $\mathrm{Mg}$ & $\mathrm{Na}$ & $\mathrm{K}$ & $\mathrm{HCO}_{3}$ & $\mathrm{SO}_{4}$ & $\mathrm{Cl}$ \\
\hline & & & & & \multicolumn{7}{|c|}{$(\mathrm{mval} / \mathrm{l})$} \\
\hline Evros & 23.0 & 8.44 & 0.68 & 5.03 & 3.91 & 1.09 & 1.88 & 0.19 & 3.72 & 2.39 & 0.76 \\
\hline Ardas & 24.0 & 8.50 & 0.36 & 2.31 & 1.82 & 0.49 & 0.35 & 0.09 & 1.80 & 0.56 & 0.35 \\
\hline Nestos & 22.9 & 8.53 & 0.36 & 3.28 & 2.85 & 0.43 & 0.35 & 0.09 & 3.06 & 0.38 & 0.23 \\
\hline Arkudorema & 21.0 & 8.48 & 0.19 & 1.63 & 1.45 & 0.18 & 0.26 & 0.07 & 1.55 & 0.21 & 0.18 \\
\hline Strymon & 21.8 & 8.30 & 0.36 & 3.45 & 2.79 & 0.66 & 0.39 & 0.11 & 3.03 & 0.55 & 0.30 \\
\hline Angitis & 18.0 & 7.80 & 0.46 & 4.40 & 3.57 & 0.83 & 0.30 & 0.04 & 4.24 & 0.17 & 0.25 \\
\hline Gallikos & 25.0 & 7.85 & 0.63 & 5.55 & 4.50 & 1.05 & 1.69 & 0.11 & 6.00 & 0.62 & 0.79 \\
\hline Axios & 17.3 & 8.25 & 0.42 & 3.56 & 2.76 & 0.80 & 0.83 & 0.12 & 3.14 & 0.55 & 0.43 \\
\hline Aliakmon & 17.9 & 8.42 & 0.41 & 4.00 & 2.84 & 1.13 & 0.17 & 0.05 & 3.63 & 0.21 & 0.19 \\
\hline Pinios & 19.6 & 8.17 & 0.50 & 5.02 & 3.37 & 1.64 & 0.26 & 0.07 & 4.71 & 0.36 & 0.21 \\
\hline Sperchios & 17.5 & 8.28 & 0.59 & 5.44 & 4.47 & 0.97 & 0.65 & 0.06 & 4.65 & 0.83 & 0.64 \\
\hline Sperchios springs & 10.0 & 7.28 & 0.18 & 1.37 & 0.98 & 0.39 & 0.26 & 0.02 & 1.41 & 0.14 & 0.08 \\
\hline Acheloos & 19.2 & 8.38 & 0.27 & 2.83 & 2.58 & 0.24 & 0.32 & 0.03 & 2.69 & 0.20 & 0.25 \\
\hline Mean & 19.8 & 8.20 & 0.42 & 3.68 & 2.91 & 0.76 & 0.59 & 0.08 & 3.36 & 0.55 & 0.36 \\
\hline Min. & 10.0 & 7.28 & 0.18 & 1.37 & 0.98 & 0.18 & 0.17 & 0.02 & 1.41 & 0.14 & 0.08 \\
\hline Max. & 25.0 & 8.53 & 0.68 & 5.55 & 4.50 & 1.64 & 1.88 & 0.19 & 6.00 & 2.39 & 0.79 \\
\hline ST. DEV. & 3.9 & 0.36 & 0.16 & 1.39 & 1.07 & 0.41 & 0.56 & 0.04 & 1.34 & 0.59 & 0.23 \\
\hline
\end{tabular}

Table Al(c). (continued)

\begin{tabular}{|c|c|c|c|c|c|c|c|c|c|c|}
\hline \multirow[t]{2}{*}{ River } & $\mathrm{NO}_{3}$ & $\mathrm{PO}_{4}$ & $\mathrm{SiO}_{2}$ & DOC & TDS & TSS & \multirow{2}{*}{$\begin{array}{c}\mathrm{O}_{2} \\
\text { (\% sat) }\end{array}$} & \multirow{2}{*}{$\begin{array}{c}\mathrm{P}_{\mathrm{CO}_{2}} \\
\text { (ppmv) }\end{array}$} & \multirow[t]{2}{*}{$\mathrm{SI}_{\text {cal }}$} & \multirow[t]{2}{*}{$\mathrm{SI}_{\mathrm{dol}}$} \\
\hline & \multicolumn{6}{|c|}{$(\mathrm{mg} / \mathrm{l})$} & & & & \\
\hline Evros & 12.32 & 1.57 & 15.46 & 3.13 & 14.23 & 73.20 & 93 & 919 & 1.03 & 0.81 \\
\hline Ardas & 2.64 & 0.16 & 10.50 & 1.11 & 5.51 & 6.40 & 116 & 306 & 0.58 & 0.37 \\
\hline Nestos & 3.04 & 0.44 & 10.92 & 1.19 & 7.45 & 11.44 & 114 & 548 & 0.98 & 0.64 \\
\hline Arkudorema & 1.21 & 0.09 & 13.92 & 2.00 & 3.92 & 8.00 & 132 & 268 & 0.39 & -0.03 \\
\hline Strymon & 3.52 & 0.35 & 12.40 & 2.44 & 7.91 & 13.70 & 101 & 951 & 0.66 & 0.41 \\
\hline Angitis & 4.84 & 0.13 & 7.55 & 0.54 & 9.48 & 2.77 & 98 & 3342 & 0.47 & 0.19 \\
\hline Gallikos & 3.30 & 0.07 & 9.55 & 1.97 & 14.82 & 2.92 & 149 & 4648 & 0.80 & 0.57 \\
\hline Axios & 5.43 & 2.63 & 9.80 & 1.31 & 8.45 & 27.20 & 96 & 859 & 0.63 & 0.40 \\
\hline Aliakmon & 3.27 & 0.17 & 9.09 & 1.83 & 8.41 & 38.00 & 100 & 679 & 0.87 & 0.72 \\
\hline Pinios & 3.27 & 0.27 & 13.65 & 1.25 & 10.70 & 11.08 & 81 & 2263 & 0.79 & 0.68 \\
\hline Sperchios & 4.51 & 0.08 & 13.23 & 0.50 & 12.32 & 11.80 & 86 & 1059 & 1.04 & 0.73 \\
\hline Sperchios springs & 1.00 & 0.08 & 15.80 & 0.74 & 3.30 & 1.57 & 69 & 3536 & -1.13 & -1.33 \\
\hline Acheloos & 2.40 & 0.03 & 3.94 & 0.74 & 6.38 & 3.62 & 97 & 580 & 0.72 & 0.25 \\
\hline Mean & 3.90 & 0.47 & 11.21 & 1.44 & 8.68 & 16.28 & 102.5 & 1535 & 0.60 & 0.34 \\
\hline Min. & 1.00 & 0.03 & 3.94 & 0.50 & 3.30 & 1.57 & 69.0 & 268 & -1.13 & -1.33 \\
\hline Max. & 12.32 & 2.63 & 15.80 & 3.13 & 14.82 & 73.2 & 149.0 & 4648 & 1.04 & 0.81 \\
\hline ST. DEV. & 2.82 & 0.76 & 3.34 & 0.79 & 3.60 & 20.02 & 21.2 & 1433 & 0.55 & 0.55 \\
\hline
\end{tabular}


Table Al(d). Average composition of Greek river waters in winter

\begin{tabular}{|c|c|c|c|c|c|c|c|c|c|c|c|}
\hline \multirow[t]{2}{*}{ River } & \multirow{2}{*}{$\begin{array}{l}\mathrm{Tw} \\
\left({ }^{\circ} \mathrm{C}\right) \\
\end{array}$} & $\mathrm{pH}$ & \multirow{2}{*}{$\begin{array}{l}\text { Cond. } \\
(\mathrm{mS} / \mathrm{cm})\end{array}$} & \multirow[t]{2}{*}{$\mathrm{TH}$} & $\mathrm{Ca}$ & $\mathrm{Mg}$ & $\mathrm{Na}$ & $\mathrm{K}$ & $\mathrm{HCO}_{3}$ & $\mathrm{SO}_{4}$ & $\mathrm{Cl}$ \\
\hline & & & & & \multicolumn{7}{|c|}{ (mval/l) } \\
\hline Evros & 6.17 & 8.08 & 0.50 & 3.17 & 2.61 & 0.57 & 1.33 & 0.14 & 2.61 & 1.30 & 0.54 \\
\hline Ardas & 7.50 & 8.50 & 0.29 & 2.37 & 2.07 & 0.30 & 0.43 & 0.08 & 1.92 & 0.29 & 0.29 \\
\hline Nestos & 6.25 & 8.39 & 0.24 & 1.87 & 1.63 & 0.24 & 0.41 & 0.08 & 1.77 & 0.34 & 0.17 \\
\hline Arkudorema & 4.50 & 8.27 & 0.09 & 0.69 & 0.64 & 0.05 & 0.17 & 0.05 & 0.64 & 0.14 & 0.11 \\
\hline Strymon & 8.70 & 8.52 & 0.43 & 3.42 & 2.63 & 0.78 & 0.69 & 0.11 & 3.19 & 0.63 & 0.35 \\
\hline Angitis & 16.0 & 8.00 & 0.51 & 4.92 & 3.90 & 1.02 & 0.61 & 0.05 & 4.72 & 0.51 & 0.25 \\
\hline Gallikos & 11.5 & 8.10 & 0.52 & 4.16 & 2.75 & 1.41 & 0.98 & 0.08 & 3.80 & 0.75 & 0.61 \\
\hline Axios & 6.3 & 8.32 & 0.52 & 3.84 & 2.56 & 1.28 & 1.50 & 0.10 & 3.68 & 1.07 & 0.52 \\
\hline Aliakmon & 6.8 & 8.50 & 0.45 & 4.32 & 2.73 & 1.58 & 0.32 & 0.05 & 4.09 & 0.37 & 0.17 \\
\hline Pinios & 7.2 & 8.45 & 0.43 & 4.18 & 2.70 & 1.48 & 0.27 & 0.04 & 3.87 & 0.34 & 0.20 \\
\hline Sperchios & 10.5 & 8.52 & 0.44 & 3.96 & 3.28 & 0.68 & 0.43 & 0.05 & 3.68 & 0.60 & 0.25 \\
\hline Sperchios springs & 7.5 & 6.90 & 0.11 & 0.84 & 0.60 & 0.24 & 0.17 & 0.01 & 0.81 & 0.08 & 0.12 \\
\hline Acheloos & 10.5 & 8.10 & 0.33 & 2.75 & 2.37 & 0.38 & 0.52 & 0.04 & 2.52 & 0.23 & 0.52 \\
\hline Mean & 8.41 & 8.20 & 0.37 & 3.11 & 2.34 & 0.77 & 0.60 & 0.06 & 2.87 & 0.51 & 0.31 \\
\hline Min. & 4.50 & 6.90 & 0.09 & 0.69 & 0.60 & 0.05 & 0.17 & 0.01 & 0.64 & 0.08 & 0.11 \\
\hline Max. & 16.00 & 8.52 & 0.52 & 4.92 & 3.90 & 1.58 & 1.50 & 0.14 & 4.72 & 1.30 & 0.61 \\
\hline ST. DEV. & 3.04 & 0.43 & 0.15 & 1.34 & 0.93 & 0.53 & 0.42 & 0.03 & 1.28 & 0.35 & 0.17 \\
\hline
\end{tabular}

Table Al(d). (continued)

\begin{tabular}{|c|c|c|c|c|c|c|c|c|c|c|}
\hline \multirow[t]{2}{*}{ River } & $\mathrm{NO}_{3}$ & $\mathrm{PO}_{4}$ & $\mathrm{SiO}_{2}$ & DOC & TDS & TSS & \multirow{2}{*}{$\begin{array}{c}\mathrm{O}_{2} \\
\text { (\% sat) }\end{array}$} & \multirow{2}{*}{$\begin{array}{c}\mathrm{P}_{\mathrm{CO}_{2}} \\
\text { (ppmv) }\end{array}$} & \multirow[t]{2}{*}{$\mathrm{SI}_{\text {cal }}$} & \multirow[t]{2}{*}{$\mathrm{SI}_{\mathrm{dol}}$} \\
\hline & \multicolumn{6}{|c|}{$(\mathrm{mg} / \mathrm{l})$} & & & & \\
\hline Evros & 11.22 & 0.78 & 11.98 & 2.66 & 9.31 & 10.60 & 74 & 938 & 0.30 & -0.23 \\
\hline Ardas & 3.52 & 0.13 & 10.40 & 1.80 & 5.44 & 18.00 & 102 & 268 & 0.45 & 0.01 \\
\hline Nestos & 5.52 & 0.32 & 11.96 & 3.76 & 4.74 & 38.25 & 95 & 358 & 0.19 & -0.25 \\
\hline Arkudorema & 1.36 & 0.21 & 12.53 & 2.42 & 2.25 & 3.20 & 104 & 156 & -0.73 & -1.32 \\
\hline Strymon & 4.55 & 0.25 & 10.06 & 2.07 & 8.47 & 23.60 & 88 & 427 & 0.76 & 0.48 \\
\hline Angitis & 5.72 & 0.29 & 12.15 & 1.87 & 11.16 & 6.40 & 79. & 2245 & 0.69 & 0.43 \\
\hline Gallikos & 3.96 & 0.15 & 9.40 & 2.81 & 10.45 & 3.80 & 95 & 1370 & 0.49 & 0.34 \\
\hline Axios & 5.57 & 2.36 & 11.31 & 1.44 & 10.89 & 23.80 & 132 & 763 & 0.57 & 0.39 \\
\hline Aliakmon & 3.21 & 0.32 & 11.90 & 1.83 & 9.38 & 10.50 & 96 & 612 & 0.84 & 0.69 \\
\hline Pinios & 4.62 & 0.22 & 13.77 & 1.51 & 9.00 & 36.40 & 118 & 646 & 0.77 & 0.61 \\
\hline Sperchios & 3.19 & 0.13 & 9.02 & 0.95 & 8.79 & 5.78 & 101 & 472 & 0.92 & 0.57 \\
\hline Sperchios springs & 1.00 & 0.25 & 10.90 & 1.04 & 2.05 & 1.40 & 79 & 4813 & -1.98 & -2.19 \\
\hline Acheloos & 2.64 & 0.07 & 3.73 & 0.99 & 6.63 & 3.78 & 101 & 924 & 0.27 & -0.13 \\
\hline Mean & 4.31 & 0.42 & 10.70 & 1.93 & 7.58 & 14.27 & 97.2 & 1076 & 0.27 & -0.04 \\
\hline Min. & 1.00 & 0.07 & 3.73 & 0.95 & 2.05 & 1.40 & 74.0 & 156 & -1.98 & -2.19 \\
\hline Max. & 11.22 & 2.36 & 13.77 & 3.76 & 11.16 & 38.25 & 132.0 & 4813 & 0.92 & 0.69 \\
\hline ST. DEV. & 2.56 & 0.60 & 2.47 & 0.82 & 3.09 & 12.67 & 15.9 & 1250 & 0.80 & 0.84 \\
\hline
\end{tabular}

Tw: water temperature, TH: total hardness, Cond.: conductivity, TDS: total dissolved solids, TSS: total suspended solids, $\mathrm{P}_{\mathrm{CO}_{2}}$ : carbon dioxide partial pressure, $\mathrm{SI}_{\text {cal }}$ : calcite saturation index, $\mathrm{SI}_{\text {dol }}$ : dolomite saturation index. 